\title{
D-ribosylation induces cognitive impairment through RAGE-dependent astrocytic inflammation
}

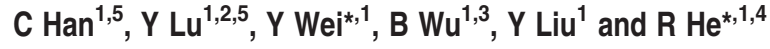

Non-enzymatic glycation of proteins by reducing saccharides for instance $\mathrm{D}$-glucose is an important post-translational modification regulating protein function. Already two centuries ago, D-glucose (GIc) was identified in the urine of diabetic patients. Recently, abnormally high level of D-ribose (Rib) in the urine of type 2 diabetics has been discovered, which is highly active in protein glycation, resulting in the production of advanced glycation end products (AGEs). Accumulation of AGEs leads to altered cellular function, for example AGE accumulation in the nervous system impairs cognitive ability, yet the mechanisms mediating this process for Rib are unknown. Here we found that treatment with Rib accelerated AGE formation in U251 and U87MG astrocytoma cells and in mouse brain, inducing upregulation of receptor for AGEs (RAGE). Astrocytoma cells with elevated levels of RAGE displayed enhanced activity of the proinflammatory nuclear transcription factor kappaB and increased expression of tumor necrosis factor alpha and glial fibrillary acidic protein. Moreover, injection of Rib induced astrocyte activation in mouse hippocampus and impaired spatial learning and memory abilities. These results indicate that mouse spatial cognitive impairment caused by Rib-derived AGEs is correlated with activation of an astrocyte-mediated, RAGE-dependent inflammatory response. This study may provide insights into the mechanism of Rib-involved cognitive impairments and diabetic encephalopathy.

Cell Death and Disease (2014) 5, e1117; doi:10.1038/cddis.2014.89; published online 13 March 2014

Subject Category: Neuroscience

Non-enzymatic glycation of proteins by reducing saccharides is a post-translational modification that leads to the formation of advanced glycation end products (AGEs), which accumulate during aging and are involved in the pathogenesis of many diseases, such as neurodegeneration and diabetes. ${ }^{1}$ Since 1815, D-glucose (Glc) has been discovered to be responsible for the sweetness in the urine of diabetics. ${ }^{2}$ Diabetes mellitus (DM) is considered as a group of metabolic diseases characterized by the high concentration of blood Glc, which is related with its complications such as diabetic encephalopathy. However, D-ribose (Rib), another important reducing monosaccharide rich in human body, involved in DM is neglected, while Glc has been best studied for its role in protein glycation and diabetic complications.

The roles of Rib in glycation and its resulting effects in vitro and in vivo have drawn increased attention in recent years. ${ }^{3}$ Whereas D-glucose has been found in the urine of type 1 diabetes patients, D-ribose has been found to have an abnormally high concentration in the urine of type 2 diabetics, ${ }^{4}$ suggesting that the diabetic patients are not only suffered from Glc metabolism disorders but may also from Rib metabolism disorders. Intraperitoneal injection of Rib into mice significantly increases their glycated serum protein and blood AGEs, although the concentration of Glc became slightly decreased, indicating that Rib can more easily induce AGEs than Glc in vivo. ${ }^{3}$ Therefore, it is necessary to compare the effects of ribosylation on AGE-induced inflammation with those of glucosylation.

Rib is present in all cells and is a key component of many important biomolecules. ${ }^{5,6}$ However, as a reducing monosaccharide, Rib has the ability to react with proteins and produce glycated derivatives. In fact previous studies from our laboratory have demonstrated that Rib glycates proteins and gives rise to AGEs more rapidly than Glc in vitro, ${ }^{7-9}$ and that Rib enhances the level of AGEs in cultured human kidney 293 (HEK293T) cells, human neuroblastoma SH-SY5Y cells, and primary cultured hippocampal neurons, leading to reduced cell viability. Moreover, the administration of Rib over a relatively long period leads to high yields of AGEs in the mouse brain and is accompanied by impaired learning and memory. ${ }^{10}$ However, the mechanism by which Rib-induced AGEs act on cells and lead to spatial cognitive impairment is hitherto unknown.

Studies on the pathological mechanisms of glycationrelated diseases for instance DM have shown that AGEs can induce cellular effects through interacting with specific cellular receptors. ${ }^{11}$ Receptor for AGEs (RAGE) is a well-characterized transmembrane protein expressed on the surface of a variety of cells, including neurons, microglia, and

\footnotetext{
${ }^{1}$ State Key Laboratory of Brain and Cognitive Sciences, Institute of Biophysics, Chinese Academy of Sciences, Beijing, China; ${ }^{2}$ School of Life Science, University of Science and Technology of China, Anhui, China; ${ }^{3}$ University of Chinese Academy of Sciences, Beijing, China and ${ }^{4}$ Key Laboratory of Mental Health, Institute of Psychology, Chinese Academy of Sciences, Beijing, China

${ }^{*}$ Corresponding author: Y Wei or R He, State Key Laboratory of Brain and Cognitive Sciences, Institute of Biophysics, Chinese Academy of Sciences, Beijing 100101, China. Tel: +86 1064888531 (YW) or +86 1064889876 (RH); Fax: +86 10 64875055; E-mail: yanwei@ moon.ibp.ac.cn (YW) or E-mail: herq@ @un5.ibp.ac.cn (RH) ${ }^{5}$ These authors contributed equally to this work.

Keywords: advanced glycation end products; astrocyte activation; D-ribose; inflammatory response; RAGE; type 2 diabetes mellitus

Abbreviations: AGEs, advanced glycation end products; Glc, D-glucose; Rib, D-ribose; DM, diabetes mellitus; RAGE, receptor for AGEs; NF- $\kappa$ B, nuclear factor kappaB; TNF- $\alpha$, tumor necrosis factor alpha; GFAP, glial fibrillary acidic protein

Received 30.9.13; revised 15.1.14; accepted 27.1.14; Edited by A Verkhratsky
} 
astrocytes. RAGE is an important signal transduction receptor activating an array of signal transduction cascades in response to AGE binding. ${ }^{12}$ In present study, we report that Rib accelerated AGE formation both in U251 and U87MG astrocytoma cells and in mouse brain, and induced a corresponding upregulation of RAGE. Astrocytoma cells with elevated levels of RAGE were found to activate proinflammatory nuclear transcription factor kappaB $(\mathrm{NF}-\kappa \mathrm{B})$ and stimulate the expression of tumor necrosis factor alpha (TNF- $\alpha$ ) and glial fibrillary acidic protein (GFAP). Moreover, Rib induced astrocyte activation in mouse hippocampus and impaired spatial learning and memory ability. These results suggest that mouse spatial cognitive impairment caused by Ribderived AGEs is correlated with the activation of an astrocytemediated, RAGE-dependent inflammatory response.

\section{Results}

Rib leads to high yield of AGEs and upregulates RAGE expression of astrocytoma cells. Rib reacts rapidly with proteins and produces significant amounts of AGEs in SH-SY5Y human neuroblastoma cells and HEK293T cells, much more than Glc. ${ }^{10}$ To investigate the ribosylation of astrocytic proteins, two astrocytoma cell lines U251 and U87MG were separately treated with 5, 10 and $20 \mathrm{mM}$ Rib. After 2 days treatment, an increase in AGEs was observed in both cell lines when compared with the untreated control group (Figures 1a and b). The increase was significant in the presence of 10 and $20 \mathrm{mM}$ Rib, showing that changes in AGEs were dependent upon the concentration of Rib used (Figures 1c and d). Under the same experimental conditions, no significant change in AGEs could be observed with Glc-treated cells. These data demonstrate that compared with Glc, Rib glycates protein faster and accelerates AGE formation in astrocytoma cells.

To elucidate whether RAGE responded to the increase of AGEs from ribosylation, western blotting was used to detect cellular levels of RAGE under the experimental conditions. As shown in Figures 1a and b, RAGE was upregulated in the presence of Rib in parallel with the cellular accumulation of AGEs while Glc-treated cells were not (Figures 1e and f). These results indicate that the elevation of cellular AGEs caused by ribosylation promotes RAGE expression in astrocytoma cells, but not glucosylation.
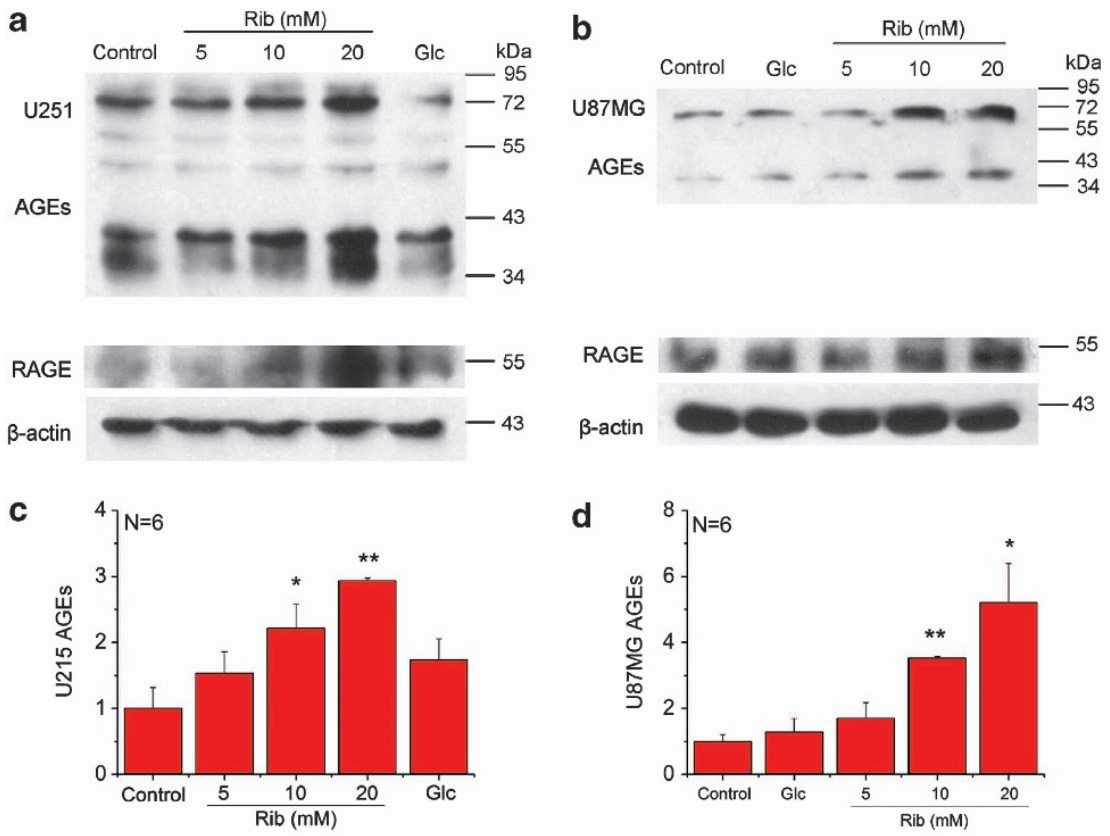

d

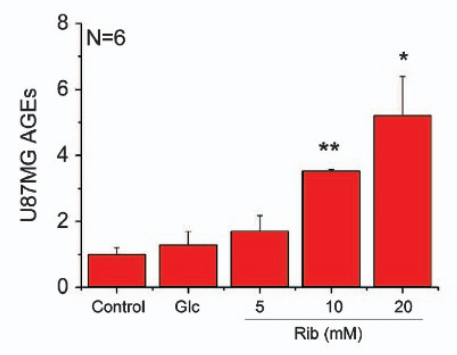

e

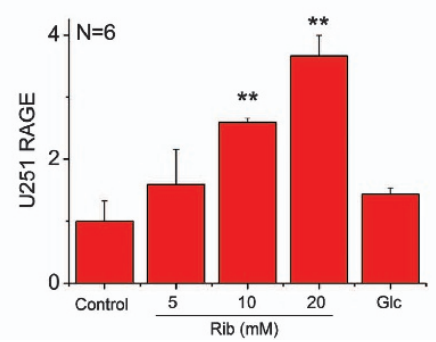

f

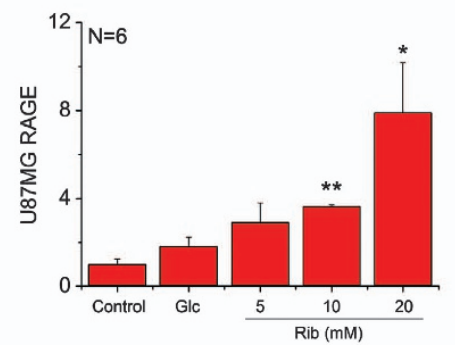

Figure 1 Elevation of AGEs and RAGE in astrocytoma cells in the presence of Rib. U251 cells (a) and U87MG cells (b) were treated with $5 \mathrm{mM}, 10 \mathrm{mM}$ and $20 \mathrm{mM}$ Rib and $20 \mathrm{mM}$ Glc, respectively, as indicated for 2 days. Untreated cells were used as controls. AGEs were detected with an anti-AGEs 6D12 monoclonal antibody, and the expression of RAGE was measured with an anti-RAGE H-300 rabbit polyclonal antibody. $\beta$-Actin was used as a loading control. Quantification results were shown in c-f, respectively. The control value was set as 1.0. All values are expressed as means \pm S.E.M. ${ }^{\star} P<0.05,{ }^{* *} P<0.01$ 
Activation of NF- $\kappa$ B and production of TNF- $\alpha$ in Rib-treated astrocytoma cells. Accumulating evidence supports that binding of ligands to RAGE results in a cellular inflammatory response by activation of the transcription factor NF- $\kappa \mathrm{B}$ and subsequent stimulation of NF- $\kappa \mathrm{B}$-regulated cytokines release. ${ }^{13,14}$ Therefore, the stimulation of RAGE expression in astrocytoma cells caused by ribosylationinduced AGEs may stimulate astrocyte inflammatory responses. To test this hypothesis, we measured the level of total NF- $\kappa$ B p65 and phosphorylated NF- $\kappa$ B p65 at Ser536 $(p-N F-\kappa B)$, and also the production of TNF- $\alpha$ in the Ribtreated astrocytoma cells. During the 2-day treatment with
$20 \mathrm{mM}$ Rib, the level of NF- $\kappa \mathrm{B}$ p65 and TNF- $\alpha$ of both cells got higher and the increase was observed markedly at $48 \mathrm{~h}$ (Supplementary Figures 1 and 2 ). NF- $\kappa$ B p65 of the cells was markedly activated when treated with Rib at concentration of $10 \mathrm{mM}$ or higher (Figures 2a-d). Furthermore, the levels of both precursor TNF- $\alpha$ in cell extracts and mature TNF- $\alpha$ secreted into culture medium increased in the presence of Rib (Figures 2a, b, e and f). However, NF- $\kappa$ B p65 activation and TNF- $\alpha$ upregulation were barely detectable in Glc groups. These results demonstrate that ribosylation produces AGEs, followed by RAGE elevation, leading to inflammatory activation with the astrocytoma cells.
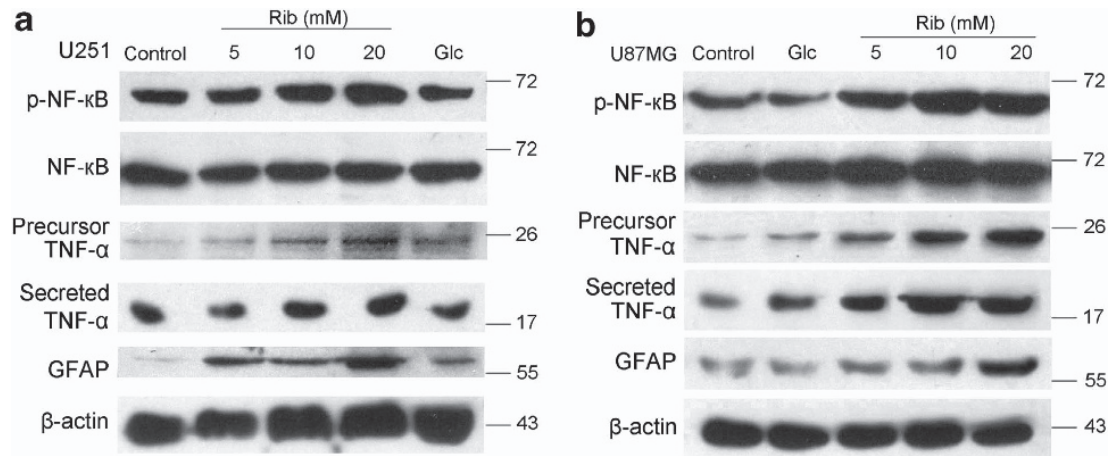

C

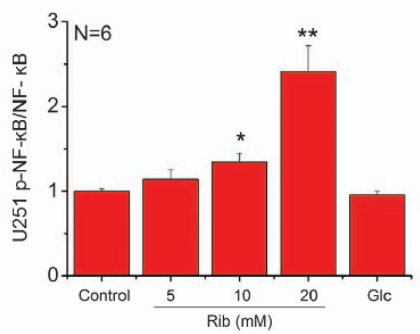

e

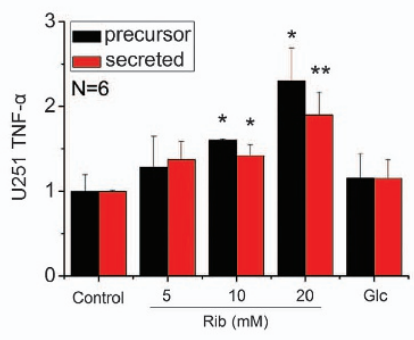

g

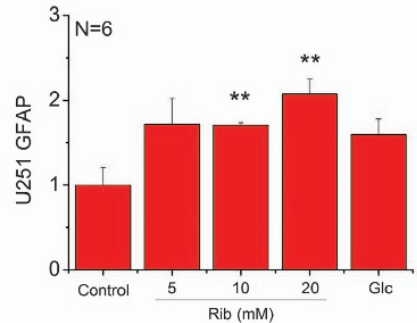

d

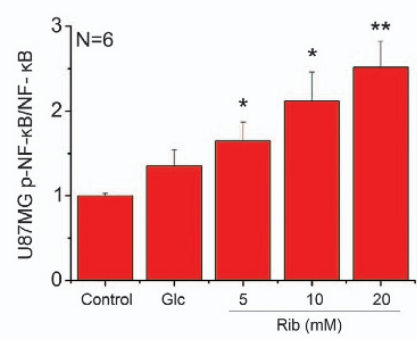

f

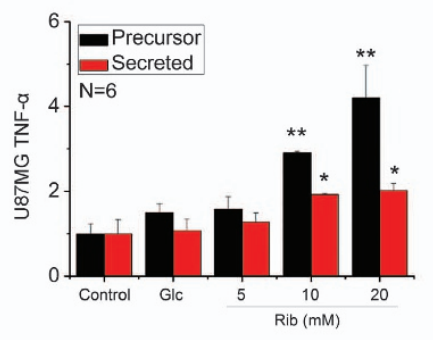

h

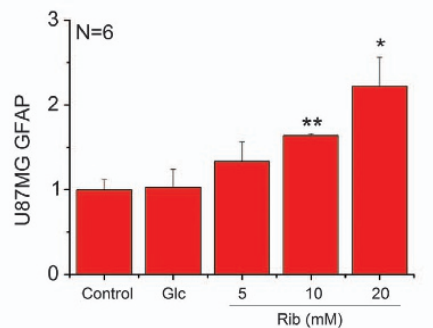

Figure 2 Upregulation of p-NF- $\kappa B$, TNF- $\alpha$ and GFAP in Rib-treated astrocytoma cells. U251 cells (panel a), and U87MG cells (panel $\mathbf{b}$ ) were treated with different concentrations of Rib and $20 \mathrm{mM}$ Glc as indicated for 2 days. Untreated cells were used as controls. The total and phosphorylated level of NF- $\kappa B$ p65, precursor TNF- $\alpha$ in cell extracts and mature TNF- $\alpha$ secreted into culture medium and the expression of GFAP were estimated using antibodies as indicated. $\beta$-Actin was used as a loading control except that NF- $\kappa B$ p 65 activation in each sample was expressed as the ratio of phosphor-NF- $\kappa B$ p65 level to total NF- $\kappa B$ p65 level. Quantification results were shown in panels $\mathbf{c}-\mathbf{h}$, respectively. The control value was set as 1.0 . All values are expressed as means \pm S.E.M. ${ }^{*} P<0.05,{ }^{*} P<0.01$ 
Increase of GFAP in Rib-treated astrocytoma cells. Proinflammatory cytokines induce astrocyte activation, which is characterized by hypertrophy of astrocytes with increased expression of GFAP. ${ }^{15}$ Although some reports argue that U87MG cells are lack of GFAP expression, ${ }^{16}$ there are quite a lot researches confirming that GFAP is expressed in U87MG cell lines. Endogenous GFAP is commonly used as a biochemical marker of U87MG differentiation. ${ }^{17-19}$ We found that the amount of GFAP increased in both of the astrocytoma cells treated with Rib (Figures $2 a$ and b).
The increase became significant when the Rib concentration was $10 \mathrm{mM}$ or higher (Figures $2 \mathrm{~g}$ and $\mathrm{h}$ ).

To further confirm the activated status of Rib-treated astrocytoma cells, immunofluorescent staining was performed in the $20 \mathrm{mM}$ Rib-treated astrocytoma cells. Compared with untreated control, cellular GFAP expression level (GFAP fluorescence intensity) increased remarkably in the two Rib-treated U251 and U87MG cells (Figures $3 b$ and c). When treated with $20 \mathrm{mM}$ Rib for 2 days, they both showed a higher GFAP immunoreactivity compared with untreated a Hoechst

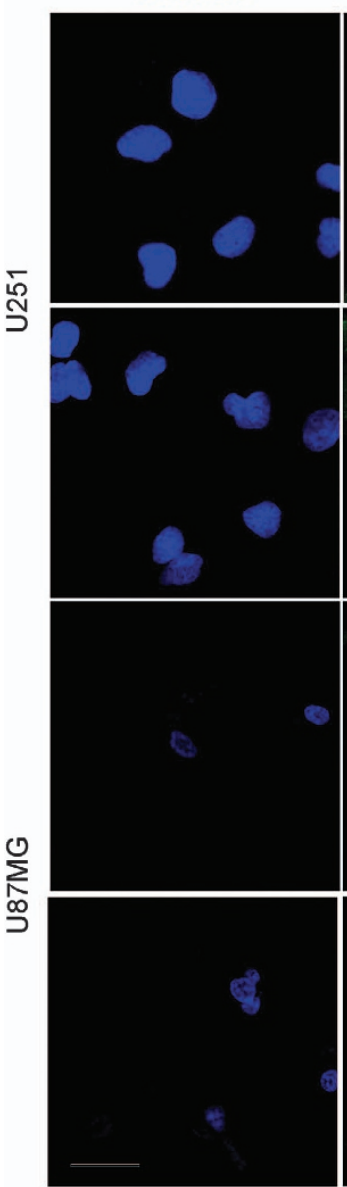

Bar=40 $\mu \mathrm{m}$

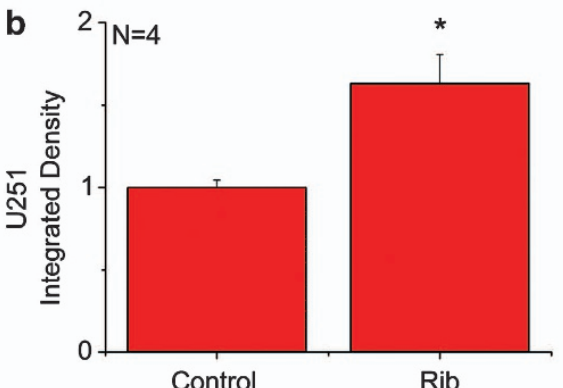

GFAP

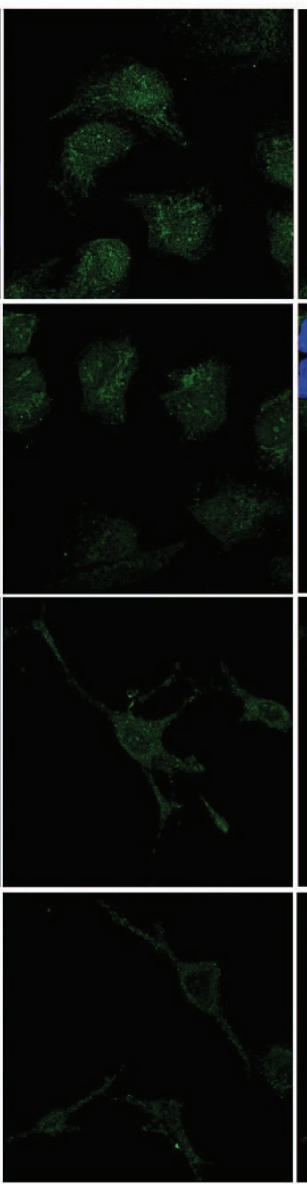

Rib merge

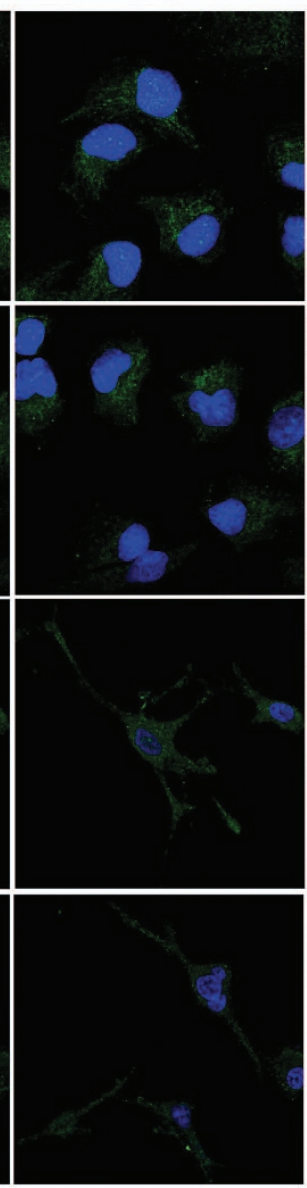

c

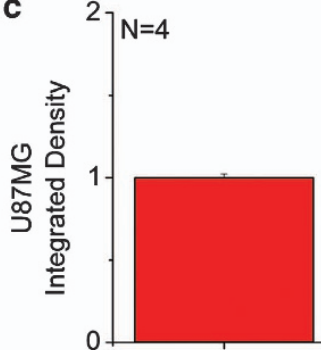

Control
BF

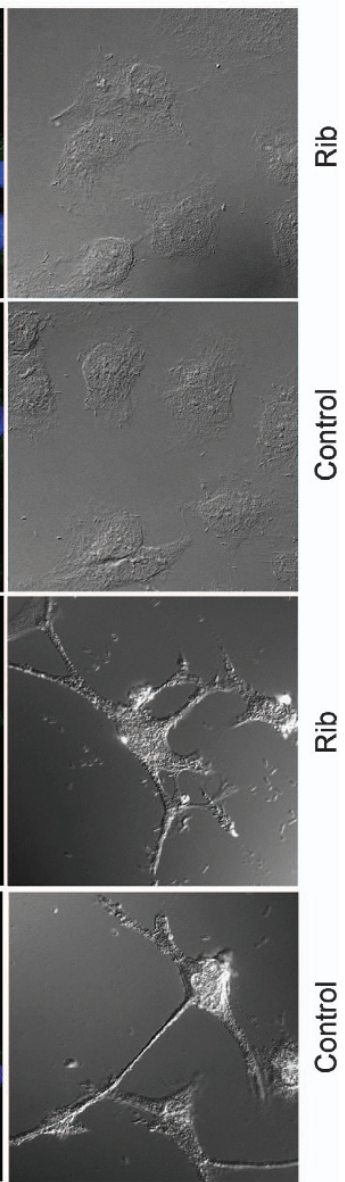

은
量

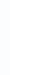

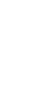

Figure 3 GFAP immunofluorescence staining on Rib-treated astrocytoma cells. U251 and U87MG cells (a) were treated with 20 mM Rib for 2 days. Untreated cells were used as controls. The distribution of GFAP was detected by immunofluorescent staining using an anti-GFAP antibody. Cell nuclei were stained with the DNA-specific fluorescent reagent Hoechst 33258. Quantification results were shown in $\mathbf{b}$ and $\mathbf{c}$, respectively. The control value was set as 1.0 . All values are expressed as means \pm S.E.M. ${ }^{\star} P<0.05,{ }^{\star \star} P<0.01$ 
control as shown in Figure 3a. These data suggest that AGEs resulted from ribosylation are able to stimulate astrocyte activation.

RAGE is required for ribosylation-induced upregulation of $\mathrm{p}-\mathrm{NF}-\boldsymbol{\kappa} \mathrm{B}, \mathrm{TNF}-\boldsymbol{\alpha}$ and GFAP. To determine whether RAGE is required for ribosylation-induced inflammatory response and astrocyte activation, a siRNA targeting against RAGE was used to knockdown the expression of RAGE in U251 and U87MG cells. Cellular RAGE expression was significantly decreased by the RAGE-specific siRNA compared with those treated with the control SiRNA (Supplementary Fig. 3). After transfection with RAGE/control siRNA for $24 \mathrm{~h}$, U251 and U87MG cells were treated with $20 \mathrm{mM}$ Rib for 2 days, then the expression levels of relative p-NF- $\kappa \mathrm{B}, \mathrm{TNF}-\alpha$ and GFAP were analyzed by western blotting (Figure 4a). As shown in Figures 4c-l, downregulation of RAGE expression in both cell lines by the specific siRNA can decline NF- $\kappa$ B activation, TNF- $\alpha$ and GFAP elevation caused by Rib treatment.

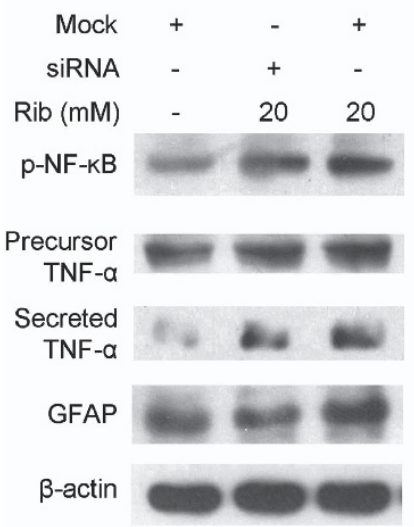

U87MG b

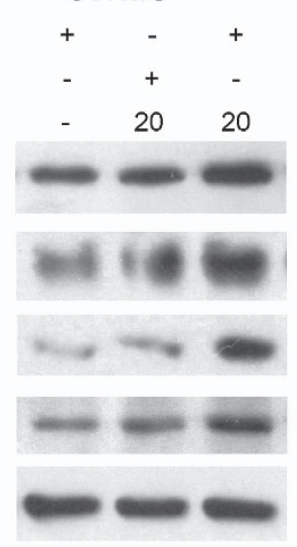

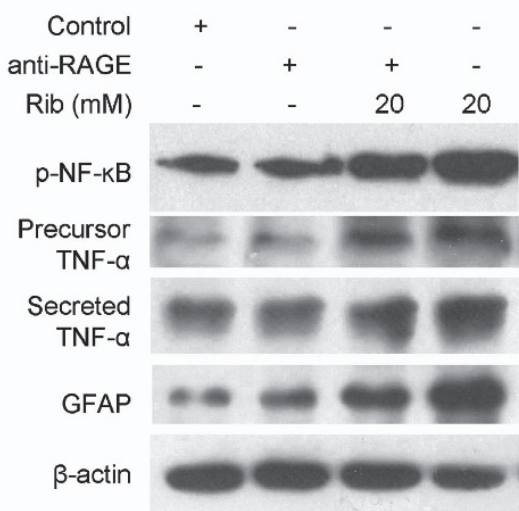

\section{U87MG}
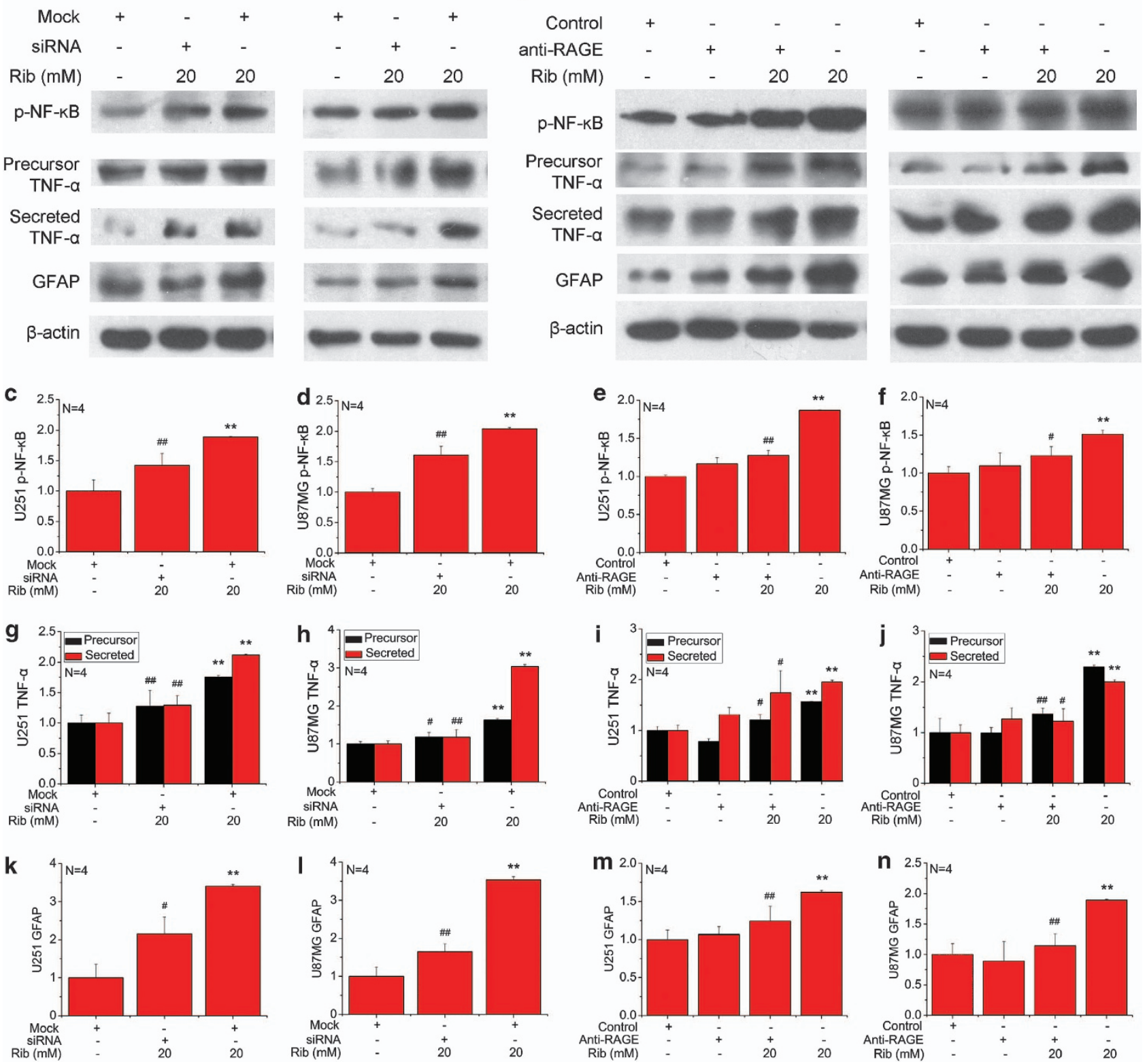

Figure 4 RAGE is required for upregulation of $p-N F-\kappa B$, TNF- $\alpha$, and GFAP in Rib-treated astrocytoma cells. U251 and U87MG cells were transfected with RAGE siRNA or control siRNA for $24 \mathrm{~h}$ and then treated with $20 \mathrm{mM}$ Rib for 2 days. After Rib treatment, the expression levels of $\mathrm{p}-\mathrm{NF}-\kappa \mathrm{B}, \mathrm{NF}-\kappa \mathrm{B}, \mathrm{TNF}-\alpha$, and GFAP were estimated by western blotting (a). Cells only transfected with control siRNA were used as negative controls and quantification results are shown in panels $\mathbf{c}, \mathbf{d}, \mathbf{g}, \mathbf{h}, \mathbf{k}$ and $\mathbf{I}$, respectively. For blocking AGE binding to RAGE, U251 and U87MG cells were pre-incubated with anti-RAGE IgG $(1 \mu \mathrm{g} / \mathrm{ml})$. The expression of $p-N F-\kappa B$, NF- $\kappa$ B, TNF- $\alpha$, and GFAP of the blocked cells treated with $20 \mathrm{mM}$ Rib for 2 days was analyzed (b). Untreated cells were used as controls. Quantification results were shown in panels $\mathbf{e}, \mathbf{f}, \mathbf{i}, \mathbf{j}, \mathbf{m}$ and $\mathbf{n}$, respectively. $\beta$-Actin was used as a loading control except that NF- $\kappa$ B p65 activation in each sample was expressed as the ratio of phosphor-NF- $\kappa$ B p65 level to total NF- $\kappa$ B p65 level. The control value was set as 1.0. All values are expressed as means \pm S.E.M. ${ }^{*} P<0.05$ and ${ }^{* *} P<0.01$ versus control group. ${ }^{\#} P<0.05$ and ${ }^{\# \#} P<0.01$ versus Rib group 
We next clarified whether the association of RAGE with its ligands was involved in the upregulation of $\mathrm{p}-\mathrm{NF}-\kappa \mathrm{B}, \mathrm{TNF}-\alpha$ and GFAP in Rib-treated astrocytoma cells. To block RAGE binding to ligands, cells were pre-incubated with a neutralizing anti-RAGE antibody and then incubated with $20 \mathrm{mM}$ Rib (Figure 4b). As shown in Figures $4 e-n$, blocking ligand-RAGE binding prevented the increase of $p-N F-\kappa B$, precursor TNF- $\alpha$ and mature TNF- $\alpha$ induced by Rib treatment. Moreover, the blockade of RAGE also inhibited ribosylation-induced GFAP elevation. These results suggest that RAGE is involved in the inflammatory response and astrocyte activation of Rib-treated astrocytoma cells.

Rib-induced elevation of AGEs in mouse serum and brain. To investigate Rib-induced ribosylation in vivo, C57BL/6J mice were injected intraperitoneally with different concentrations of Rib for 10 days, and the levels of glycated serum proteins were determined. Compared with saline control, the increase in glycated serum proteins became

Table 1 Concentrations of glycated serum protein

\section{Treatment}

$0.4 \mathrm{~g} / \mathrm{kg} \mathrm{Rib}$

$0.8 \mathrm{~g} / \mathrm{kg}$ Rib

$1.6 \mathrm{~g} / \mathrm{kg}$ Rib

$3.2 \mathrm{~g} / \mathrm{kg}$ Rib

Control
Glycated serum protein ( $\mathrm{mM})$

$5.32 \pm 0.22$
$6.57 \pm 0.37$
$7.62 \pm 0.67^{\star}$
$9.32 \pm 0.68^{\star *}$
$5.79 \pm 0.44$

$6.57 \pm 0.37$

$7.62 \pm 0.67^{*}$

$5.79 \pm 0.44$
Mice were injected with Rib as indicated for 10 days and serum was taken for assays of glycated serum protein. All values are expressed as means \pm S.E.M. ${ }^{\star} P<0.05,{ }^{* \star} P<0.01$ significant when mice were injected with Rib at $0.8 \mathrm{~g} / \mathrm{kg}$ or higher (Table 1). We also measured changes in serum AGE formation in mice treated with different concentrations of Rib. Rib-injected mouse serum AGEs were markedly elevated at concentrations of 1.6 and $3.2 \mathrm{~g} / \mathrm{kg}$ (Figures $5 \mathrm{a}$ and b). Similar results were also observed when serum pentosidine as another marker was determined (Figure $5 c$ ).

Agnew and Crone have studied the permeability of hexoses and pentoses through the capillaries of the rabbit brain. ${ }^{20}$ Their results indicate that Rib can pass through the blood-brain barrier and enter the brain tissue by simple diffusion; hence Rib may glycate brain proteins. We measured AGEs in the mouse brain with western blotting. As shown in Figure 5d, intraperitoneal injection of Rib for 10 days led to an increase of AGE formation in the mouse brain compared with saline as control. These results demonstrate that Rib elevates the glycation of proteins, resulting in acceleration of AGE formation both in the mouse brain and circulatory system.

Upregulation of RAGE, $p-N F-\kappa B$, TNF- $\alpha$ and GFAP in the brain of mice injected with Rib. We next examined whether the elevation of brain AGEs caused by Rib injection altered RAGE levels and inflammatory response. Western blot analysis revealed that RAGE levels increased in Ribtreated mouse brains in parallel with the increase in AGE formation (Figures $5 e$ and $\mathrm{f}$ ). These data indicate that Ribinduced AGE accumulation can upregulate the multi-ligand receptor RAGE in the mouse brain.

Then we determined the change of $p-N F-\kappa B / N F-\kappa B$ ratio, TNF- $\alpha$ and GFAP in the brain of Rib-injected mice by western a

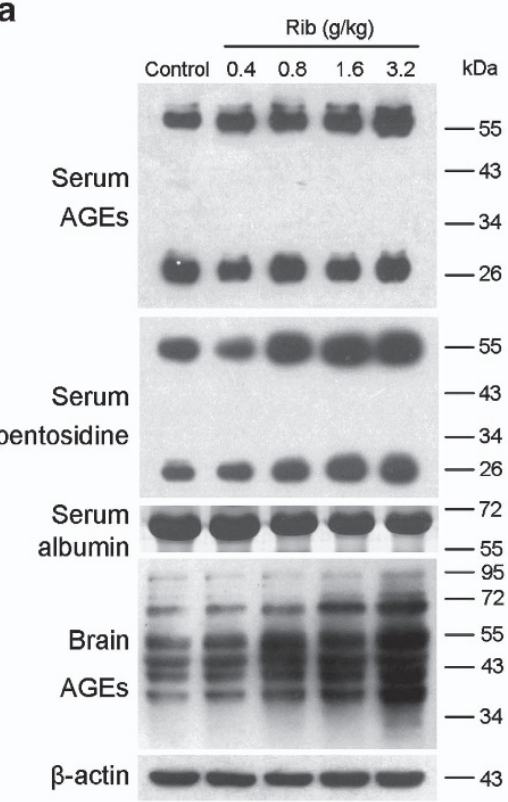

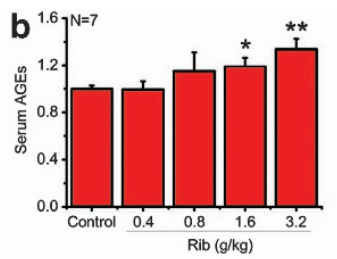

e
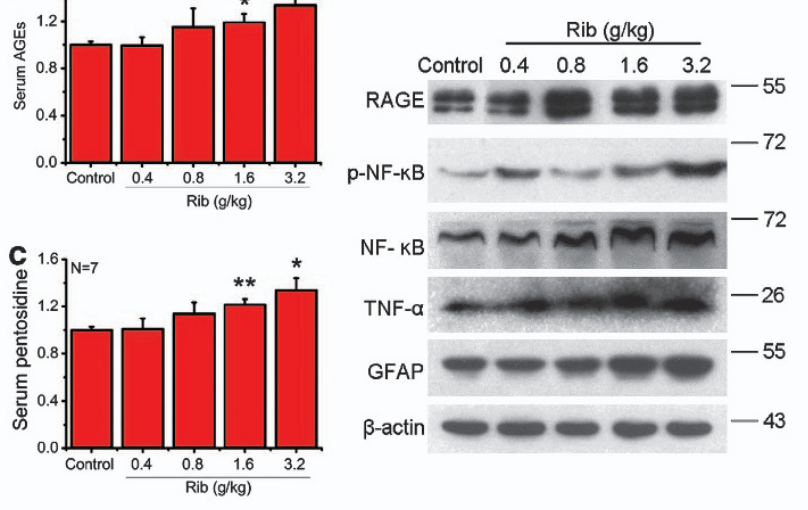

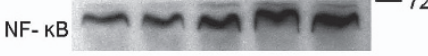
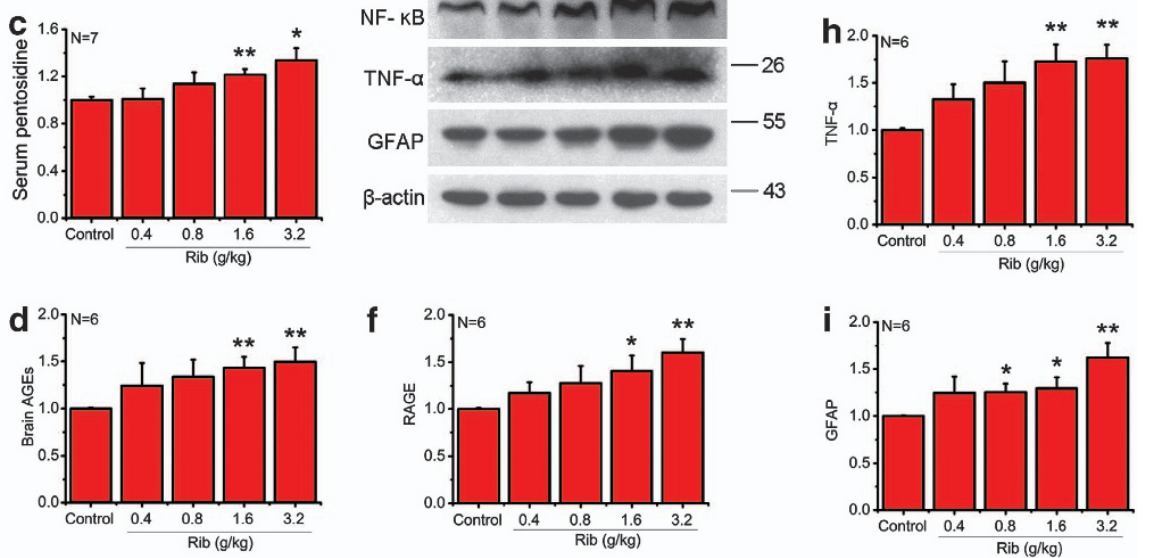

f

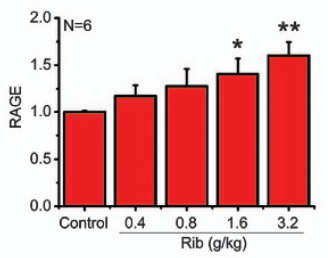

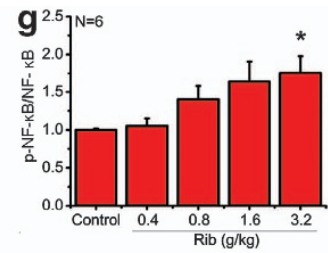

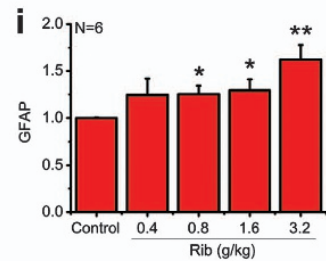

Figure 5 Intraperitoneal injection of Rib elevates the AGE, RAGE level and production of $p-N F-\kappa B$, TNF- $\alpha$, and GFAP in mouse serum and brain. Mice were injected intraperitoneally with Rib in different doses as indicated each day for 10 days. Serum AGEs were detected by western blotting with an anti-AGEs 6D12 monoclonal antibody and an anti-pentosidine monoclonal antibody. Serum albumin level was used as a loading control (a). AGE (a), p-NF- $\kappa B$, TNF- $\alpha$, and GFAP level (panel e) of mouse brain were probed by corresponding antibodies. $\beta$-Actin was used as a loading control. Quantification results were shown in $\mathbf{b}-\mathbf{d}$ and $\mathbf{f}$-i, respectively. $\beta$-Actin was used as a loading control except that NF- $\kappa$ B p65 activation in each sample was expressed as the ratio of phosphor-NF- $\kappa$ B p65 level to total NF- $\kappa$ B p65 level. The saline control value was set as 1.0. All values are expressed as means \pm S.E.M. ${ }^{*} P<0.05,{ }^{* *} P<0.01$ 
blotting. As shown in Figures $5 \mathrm{e}, \mathrm{g}$ and $\mathrm{h}$, the levels of $\mathrm{p}-\mathrm{NF}-\kappa \mathrm{B} / \mathrm{NF}-\kappa \mathrm{B}$ and TNF- $\alpha$ increased in according with Rib concentration. Similarly, GFAP, the protein closely related to astrocyte activation, also increased significantly in the brain of mice treated with Rib at $0.8 \mathrm{~g} / \mathrm{kg}$ or higher (Figure $5 \mathrm{i}$ ). These results suggest that Rib-induced RAGE elevation may result in inflammatory response and astrocyte activation in the mouse brain.

Astrocyte activation in the hippocampus of Rib-injected mice. To examine for alterations in astrocytes in brains of Rib-injected mice, the morphology of astrocytes was evaluated using GFAP immunohistochemistry. As shown in Figure 6, GFAP immunostaining revealed an extensive activation of astrocytes in the hippocampus of mice injected with Rib for 10 days. In saline control, GFAP staining was diffusely low as seen with both low- and high-magnification views (Figures 6a, d, g and j). GFAP immunostaining was slightly enhanced by Rib at $0.8 \mathrm{~g} / \mathrm{kg}$ (Figures $6 \mathrm{~b}, \mathrm{e}, \mathrm{h}$ and $\mathrm{k}$ ). When the injected Rib concentration was up to $3.2 \mathrm{~g} / \mathrm{kg}$ (Figures 6c, f, i and I), a pronounced increase in the GFAP signal was observed in all hippocampal regions (Figure 6m). GFAP-positive cells exhibited markedly enlarged cell bodies and thickened processes, typical features of an activated phenotype. These results demonstrate that intraperitoneal injection of Rib can activate astrocytes in mouse hippocampus.

Impairment of spatial learning and memory in Rib-injected mice. Smith and colleagues have studied the relationship between advanced Maillard reaction end products and Alzheimer's disease pathology. They found that AGEs increase in the neurofibrillary tangles and senile plaques in brain tissue from patients with Alzheimer's disease. ${ }^{21}$ AGEs are also co-localized with astrocytes and microglial cells in Alzheimer's disease brain. ${ }^{22}$ We therefore tested the behavior of Rib-treated mice in the Morris water maze to assess spatial learning and memory. Before the Morris water maze test, the weights of mice and the strength of mice muscle were measured to make sure there were no remarkable physical differences between Rib-injected groups and control ones (Supplementary Figures $4 A$ and $B$ ). An open field test was also performed. As shown in Supplementary Figures 4C-E, no significant differences in velocity, travel distance and time spent in center could be observed among the mice of all the groups $(P>0.05, n=12)$. The degree of Rib-induced spatial learning and memory impairment differed according to the concentrations as indicated in Figure 7. During the training session, all mice improved their performance as indicated by shortened escape latencies over successive days. Escape latencies of mice injected with Rib $(0.4,0.8$ and $1.6 \mathrm{~g} / \mathrm{kg})$ were not significantly different compared with the control group. However, the escape latencies of mice injected with Rib at concentration of $3.2 \mathrm{~g} / \mathrm{kg}$ were significantly higher than that of control mice on day 8 (Figure 7a). During the probe trial, mice treated with Rib at different concentrations decreased in the percentages of searching time and distance in target quadrant. Compared with the control group, mice treated with Rib at the concentrations of 1.6 and $3.2 \mathrm{~g} / \mathrm{kg}$ showed significant less time and distance in target quadrant (Figure 7b). However, all groups of mice showed no significant differences in visual platform testing (Figure 7c, $P>0.05, n=12)$. These results indicate that spatial learning and memory ability of Rib-treated mice are impaired, especially the mice treated with high concentrations of Rib.

\section{Discussion}

D-ribose, a naturally occurring sugar, is found in all cell types and participates in numerous processes, especially those related with energy production. Rib can be obtained from the diet, especially from foods containing high amounts of riboflavin, such as yeast extract, liver, wheat bran, eggs, meat, cheese, and milk. ${ }^{23-25} \mathrm{Rib}$ is also ingested as a supplement for cardiac energetic metabolism for instance the patients with stable coronary artery disease as the sugar provides the structural foundation for ATP. ${ }^{26,27}$ However, as a reducing saccharide with an active aldehyde group in the open chain form, Rib can react with amino groups to initiate protein glycation rapidly. In recent years, ribosylation has attracted more attention due to its role in protein glycation and its subsequent effects such as protein aggregation and cellular dysfunction. Currently, it has been found that the levels of uric Rib of type 2 diabetics are significantly higher than those of age-matched normal control. ${ }^{4}$ This work demonstrated that mouse spatial cognitive impairment is caused by Rib-derived AGEs, which is correlated with activation of an astrocytemediated, RAGE-dependent inflammatory response. Moreover, diabetic encephalopathy, whose relationship with increased incidence of dementia has been established, is proved to be the most relevant risk factor for cognitive dysfunction. ${ }^{28-30}$ Therefore, these results may provide insights into the mechanism of Rib-involved cognitive impairments and diabetic encephalopathy.

Previous studies from our laboratory have demonstrated that in vitro glycation of bovine serum albumin, neuronal Tau and $\alpha$-synuclein with Rib are much faster than with $\mathrm{Glc}^{7-9}$ and that Rib treatment promotes AGE production in HEK293T and SH-SY5Y cells. ${ }^{10}$ In this study, we confirmed the quick AGE formation effect of Rib in U251 and U87MG cells. These data demonstrate that Rib induces protein glycation and enhances the yield of AGEs in different types of cells. Furthermore, our recent data have shown that injection of Rib for 30 days leads to a significant higher level of AGEs in mouse serum and brain; ${ }^{10}$ in addition, according to results from the present work, administration with Rib for a shorter period (10 days) increased protein glycation in mouse serum and elevated the level of AGEs in the mouse brain. In contrast, Glc does not produce a significant glycation effect in vitro and in vivo under the same experimental conditions. ${ }^{11}$ These data together provide evidence that Rib is an efficient glycator that actively participates in protein glycation and AGE formation both inside (endogenous glycation) and outside the body (exogenous glycation).

AGEs have an important role in the pathogenesis of some chronic diseases by a receptor-mediated mechanism. ${ }^{1}$ The well-characterized receptor for AGEs, known as RAGE, is present in a variety of cells, including 

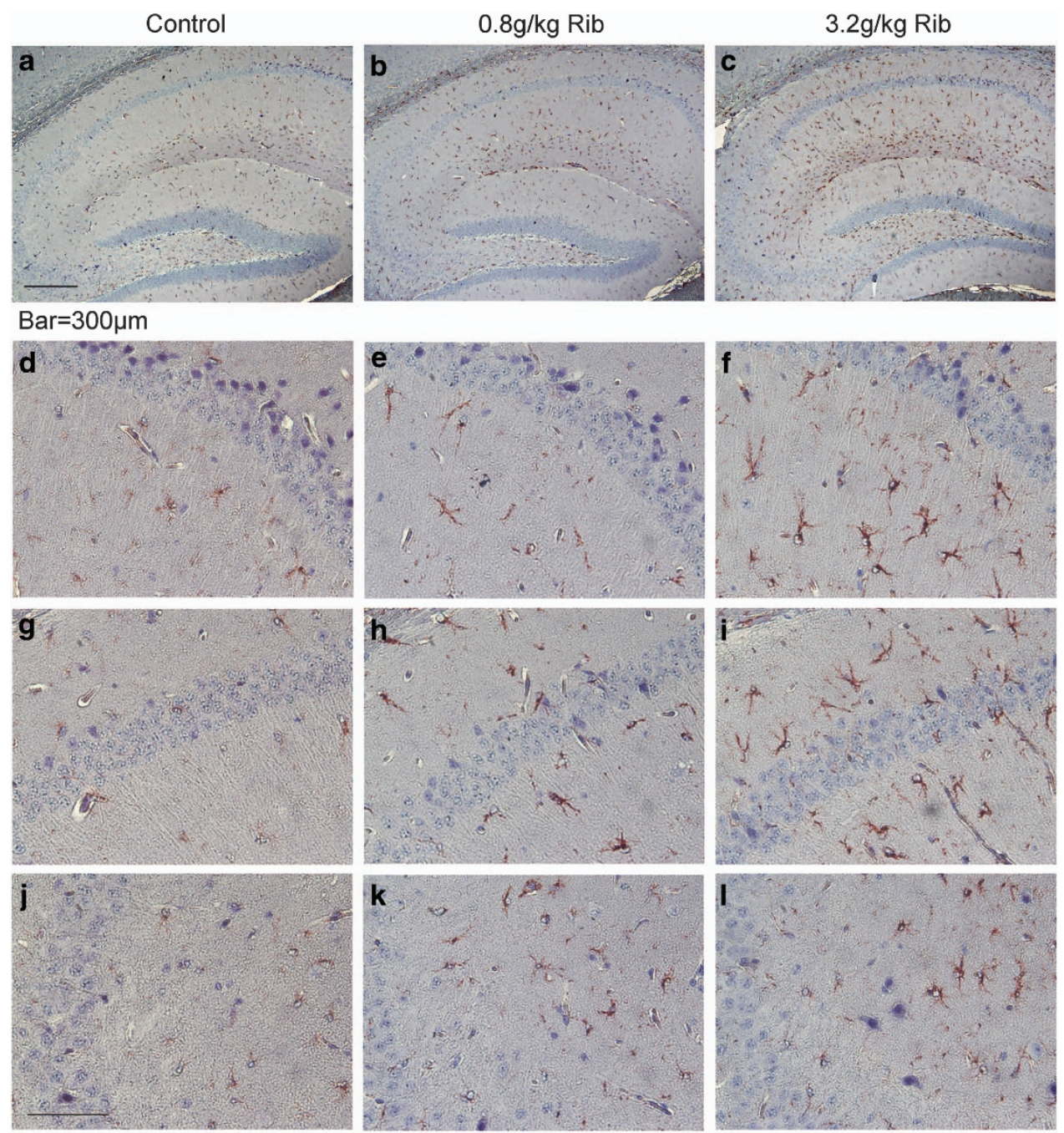

Bar=100 $\mu \mathrm{m}$

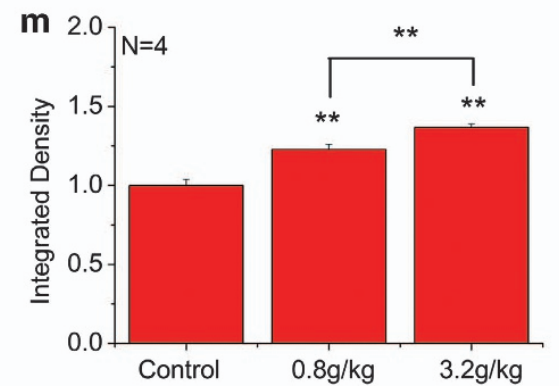

Figure 6 Astrocyte activation in the hippocampus of Rib-injected mice. Mice treated with saline (a, d, g, and j), Rib at $0.8 \mathrm{~g} / \mathrm{kg}(\mathbf{b}, \mathbf{e}, \mathbf{h}$, and $\mathbf{k})$ and at $3.2 \mathrm{~g} / \mathrm{kg}(\mathbf{c}, \mathbf{f}, \mathbf{i}$, and $\mathbf{~})$ for 10 days, and the brain slices including hippocampal formation were prepared as described in Materials and Methods and reactive astrocytes were analyzed using an anti-GFAP antibody. Reactive astrocytes were significantly increased in the hippocampal area, and immunohistochemistry shows distribution of the increased reactive astrocytes in the CA1 (d, e and f), CA2 ( $\mathbf{g}, \mathbf{h}$ and i) and CA3 (j, $\mathbf{k}$ and $\mathbf{l}$ ) regions. GFAP immunohistochemistry stained with hematoxylin counterstaining. Quantification results were shown in $\mathrm{m}$. The control value was set as 1.0. All values are expressed as means \pm S.E.M. ${ }^{* \star} P<0.01$

astrocytes. ${ }^{31}$ Here, we found that treatment with Rib elevated the RAGE expression in astrocytoma cells, and the elevation in the expression of RAGE correlated with the elevation of cellular AGE level. In addition, pre-incubating Rib with bovine serum albumin in vitro also induced AGE-mediated upregulation of RAGE in astrocytoma cells, and this effect occurred sooner than treating with Rib alone (Supplementary Figure 5).

RAGE is expressed in many tissues including the brain. Except for skin and lung, most tissues do not express large amounts of RAGE under physiological conditions, but in the course of some chronic disorders, RAGE expression is 

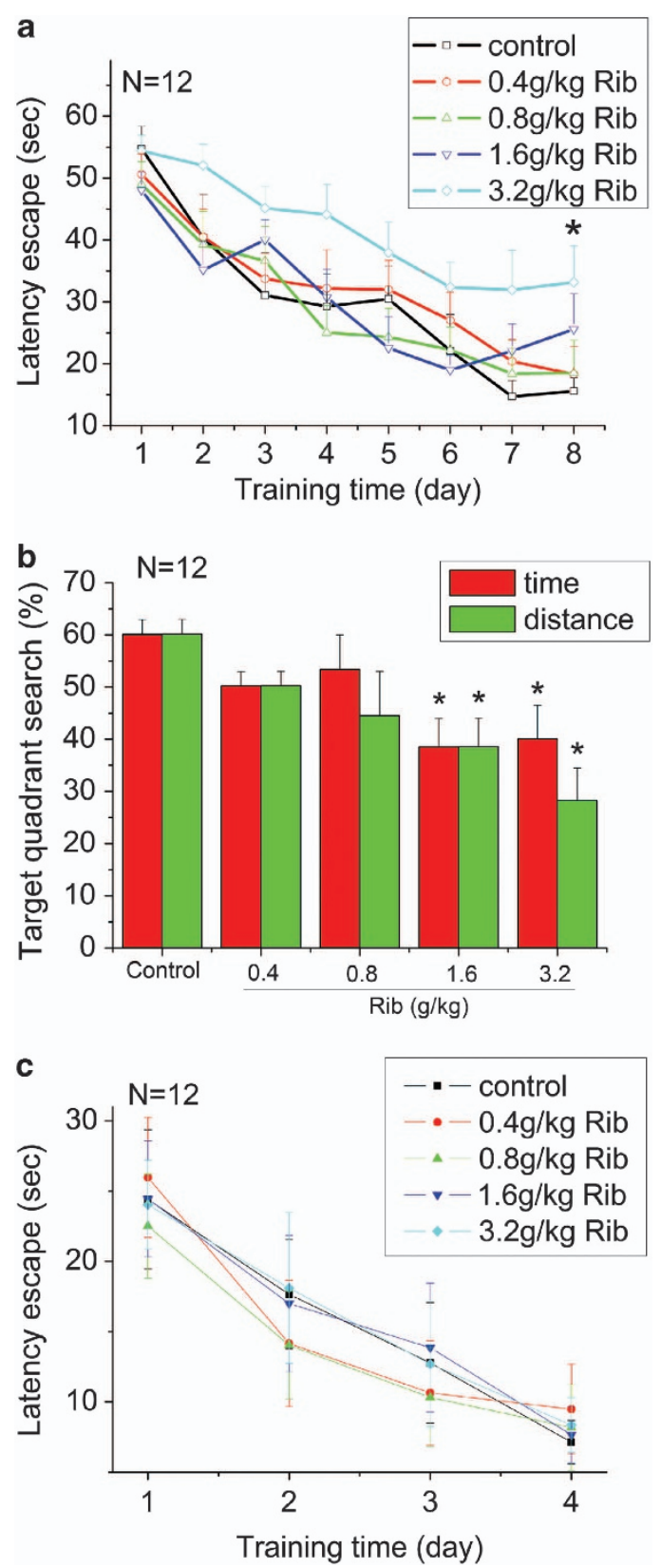

Figure 7 Decline in the performance of mice injected with Rib in the Morris water maze test. Conditions for the injection of Rib at different doses were the same as those given in Figure 5. The length of time mice took to find the hidden platform was recorded as latency of escape during each of the eight training days (a). The percent of the searching time and distance spent in the quadrant where the platform was removed during the probe trial is shown in $\mathbf{b}$. A visual platform test was also performed, and the length of time mice took to find the platform was recorded as latency of escape (c). All values are expressed as means \pm S.E.M. ${ }^{*} P<0.05$

elevated when either ligands accumulate and/or transcription factors regulating RAGE are activated. ${ }^{12,32}$ However, in the present study, the RAGE level in the brains of Rib-treated mice increased significantly and coincidently with the change of brain AGE formation. These data along with the results from cultured astrocytoma cells treated with Rib indicate that similar to those generated spontaneously under physiological or pathological conditions, AGEs resulting from ribosylation can also upregulate the RAGE expression.

As an important signal transduction receptor, RAGE can activate an array of signal transduction cascades, including activation of the proinflammatory transcription factor $\mathrm{NF}-\kappa \mathrm{B}$ and subsequent expression of genes regulated by NF- $\kappa \mathrm{B} .{ }^{14,33}$ According to the present study, results from the Rib-treated astrocytoma cells and Rib-injected mice suggest that ribosylation induced RAGE upregulation and $\mathrm{NF}-\kappa \mathrm{B}$ activation both in vitro and in vivo. The NF- $\kappa \mathrm{B}$ activation in this study was confirmed by the increased ratio of phosphor-NF- $\kappa$ B p 65 level to total NF- $\kappa \mathrm{B}$ p65 level. NF- $\kappa \mathrm{B}$ p65 (also known as Rel $\mathrm{A}$ ) is one of the predominant components of NF- $\kappa$ B-heterodimer p65/p50. ${ }^{34}$ New synthesis of phosphorylated NF- $\kappa$ B p 65 itself generates an excess of transcriptionally activated NF- $\kappa \mathrm{B}$ p65. ${ }^{35}$ Meanwhile, the activated $\mathrm{NF}-\kappa \mathrm{B}$ migrates into the nucleus, binds to specific NF- $\kappa$ B response elements in the promoters of target genes, such as TNF- $\alpha$, to induce TNF- $\alpha$ transcription. ${ }^{36,37}$ Here we found that, after Rib treatment, TNF- $\alpha$ in astrocytoma cells and in the mouse brain was upregulated parallel with the upregulation of $\mathrm{NF}-\kappa \mathrm{B}$ activation. In addition, one consequence of NF- $\kappa \mathrm{B}$ activation is the upregulation of RAGE, as the RAGE promoter itself contains two functional NF- $\kappa$ B-binding sites. ${ }^{38,39}$ Therefore, RAGEdependent NF- $\kappa$ B activation described here results in TNF- $\alpha$ release and RAGE upregulation, which, in turn, could contribute to ensuring the maintenance and amplification of sustained $\mathrm{NF}-\kappa \mathrm{B}$ activation.

Astrocytes are reported to be highly responsive to the proinflammatory cytokine TNF- $\alpha$ and to have an important role in maintaining normal homeostasis as well as regulating inflammatory responses in the CNS. Many neurological conditions are accompanied by reactive changes in astrocytes, which are characterized by an increase in the cellular expression of the astrocyte-specific protein GFAP. In the present study, we found that GFAP expression was increased in the Rib-treated astrocytoma cells and in the brains of Ribtreated mice. Immunohistochemistry also showed an extensive activation of astrocytes in the hippocampus of the mice injected with Rib. Furthermore, the ribosylation-induced upregulation of $\mathrm{p}-\mathrm{NF}-\kappa \mathrm{B}$ p65, TNF- $\alpha$ and GFAP were attenuated when RAGE expression or ligand-binding level was interrupted. These results suggest that AGEs generated by ribosylation can act on astrocytes manifesting as RAGEdependent NF- $\kappa \mathrm{B}$ activation and astrocyte activation.

The spatial learning and memory ability of Rib-treated mice were impaired, especially in the mice treated with higher concentrations of Rib. AGEs can inhibit cell proliferation and are directly neurotoxic to cultured neurons. ${ }^{40,41}$ According to previous studies from our laboratory, ribosylation promotes proteins to form aggregation, generates cytotoxic AGEs, decreases cell viability of HEK293T and SH-SY5Y cells, and thus might result in direct damage to the nervous system. In contrast, astrocyte activation is implicated as a critical mechanism responsible for the pathogenesis and the progressive nature of neurodegenerative diseases. ${ }^{42} \mathrm{~A}$ number of studies have demonstrated that patients with dementia have increased CSF levels of GFAP. ${ }^{43}$ Immunohistochemical studies have shown that in the brain of Alzheimer's disease patients, most of the extra-perikaryal AGE deposits are 
co-localized with GFAP-positive reactive astrocytes. ${ }^{22}$ Moreover, astrocyte activation leads to the production of cytotoxic cytokine-like molecules that may induce further neuronal cell injury and death resulting in dysfunction of the brain. ${ }^{44}$ Clinical studies have demonstrated that abnormal levels of proinflammatory cytokines such as TNF- $\alpha$ are associated with memory decline. ${ }^{45}$ Hence, the clinical evidence along with the results of the present study reveals a potential role of astrocytes in the pathological mechanism underlying the relation between AGE accumulation and cognitive decline, that is, accumulated AGEs act on astrocytes and result in spatial cognitive impairment via RAGE-dependent inflammatory response and astrocyte activation.

In summary, we have shown that Rib rapidly reacts with proteins and produces AGEs in astrocytoma cells. The increase in RAGE expression is correlated with the ribosylation-induced AGE elevation both in astrocytoma cells and in the mouse brain, resulting in RAGE-dependent $\mathrm{NF}-\kappa \mathrm{B}$ activation and astrocyte activation and subsequent impairment of spatial learning and memory ability. These data imply a possible involvement of glycation induced by Rib in the pathological mechanism of diseases with cognitive impairment, in particular of diabetic encephalopathy.

\section{Materials and Methods}

Ethics statement. The handling of mice and experimental procedures were approved by the Animal Welfare and Research Ethics Committee of the Institute of Biophysics, Chinese Academy of Sciences (Permit Number: SYXK2010-128).

Cell culture and treatments. Human astrocytoma cell lines U251 and U87MG were from the Cell Resource Center (IBMS, CAMS/PUMC, China). The cells were cultured in Eagle's Minimum Essential Medium (Hyclone, Logan, UT, USA) supplemented with $100 \mathrm{IU} / \mathrm{ml}$ penicillin and $100 \mu \mathrm{g} / \mathrm{ml}$ streptomycin (Gibco, Big Cabin, OK, USA) at $37^{\circ} \mathrm{C}$ in a humidified $5 \% \mathrm{CO}_{2}$ incubator as described. ${ }^{46}$ The medium contained $10 \%$ fetal bovine serum (Gibco) with the U87MG media further supplemented with $1 \%$ non-essential amino acids (Hyclone). For all experiments, the culture medium was replaced with serum-free medium before various treatments. Cells were treated with Rib (Amresco, Solon, OH, USA) at concentrations of 5,10 and 20 or $20 \mathrm{mM}$ Glc (Sigma, St. Louis, MO, USA) for $48 \mathrm{~h}$. Cells were then collected to prepare cellular extracts for western blotting, and the culture medium was centrifuged for detecting secreted TNF- $\alpha$.

To verify the involvement of RAGE, astrocytoma cells were treated with a RAGE-specific siRNA to reduce RAGE expression. The target siRNA for RAGE (sc-36374) and a negative-control siRNA (sc-37007) with an irrelevant sequence were obtained from Santa Cruz Biotechnology (Santa Cruz, Dallas, TX, USA). Cells were grown to $60-80 \%$ confluence and then transfected with the siRNA duplex $(30 \mathrm{nM})$ using siRNA transfection reagent (Santa Cruz), according to the manufacturer's instructions. The transfected cells were then treated with $20 \mathrm{mM}$ Rib for 2 days. Expression of RAGE, phosphor-NF- $\kappa$ B p65, NF- $\kappa B$ p65, TNF- $\alpha$ and GFAP were determined by western blotting.

To test the necessity of the AGE-RAGE binding for inflammatory response induced by ribosylation, astrocytoma cells of $80 \%$ confluence were pre-incubated with anti-RAGE IgG ( $1 \mu \mathrm{g} / \mathrm{ml}$, Santa Cruz) for $1 \mathrm{~h}$ to block the binding of RAGE, and then treated with $20 \mathrm{mM}$ Rib for $48 \mathrm{~h}$ before subsequent biochemical assays.

Rib administration. Male C57BL/6J mice (8-10 weeks) were from Vital River Laboratory Animal Technology (Beijing, China). After 1 week of acclimatization to the cages, mice were randomly divided into five groups and received daily intraperitoneal injections for 10 days with different doses of Rib $(0.4,0.8,1.6$ and $3.2 \mathrm{~g} / \mathrm{kg}$, respectively), and control group were injected with $0.9 \%$ saline. All mice were maintained in animal facilities under pathogen-free conditions.

Open field test. After injections, mice were first subjected to an open field test. The apparatus consisted of a $50 \times 50 \mathrm{~cm}$ open arena with $40 \mathrm{~cm}$ high walls.
The entire test arena was adjusted to even illumination. Mice were placed in the center of the arena, and their activity was recorded for $5 \mathrm{~min}$. For analysis, a $4 \times 4$ grid was placed over the video, and the centre square was defined as the central zone. The average velocity and total distance traveled were used as measures of overall motor activity. The time mice traveled in the central zone were also quantified.

Morris water maze test. The Morris water maze test was performed as described previously. ${ }^{47}$ The experimental apparatus consisted of a circular water tank ( $120 \mathrm{~cm}$ in diameter, $35 \mathrm{~cm}$ in height), containing water $\left(23 \pm 1^{\circ} \mathrm{C}\right)$ to a depth of $15.5 \mathrm{~cm}$, which was rendered opaque by adding white food dye. A platform $(4.5 \mathrm{~cm}$ in diameter, $14.5 \mathrm{~cm}$ in height) was submerged $1 \mathrm{~cm}$ below the water surface and placed at the midpoint of one quadrant. The water tank was located in a test room, which contained various prominent visual cues. Each mouse received three periods of training per day for eight consecutive days. Latency to escape from the water maze (finding the submerged escape platform) was calculated for each trial. On day 9 , the probe test was carried out by removing the platform and allowing each mouse to swim freely for $60 \mathrm{~s}$. The time and distance that mice spent swimming in the target quadrant (where the platform had been located during hidden platform training) were measured. After the probe test, a visual platform was put in the opposite position of the place where the submerged platform was placed. Each mouse received three periods of training per day for four consecutive days. Latency to escape from the water maze (finding the visual platform) was calculated for each trial. All data were recorded with a computerized video system.

Animal sample collection. After 10 days injection, mice were killed and their blood was collected as described previously ${ }^{48}$ and centrifuged $\left(2000 \times \mathrm{g}, 20 \mathrm{~min}, 4^{\circ} \mathrm{C}\right)$. Serum was aspirated and used for assay of glycated serum proteins using a kit obtained from the Nanjing Jiancheng Bioengineering Institute (China) according to the manufacturer's guidelines. ${ }^{49}$ At the same time, brains were removed and total protein was extracted for western blotting using protein extraction kit (Beyotime, Nantong, China) according to the manufacturer's instruction

Gel electrophoresis and western blotting. The level of AGEs in cultured cells, brain tissues, and mice sera were determined by western blotting. The same method was used to analyze the expression of RAGE, $p-N F-\kappa B$, $N F-\kappa B, T N F-\alpha$, and GFAP in cells and brains of mice treated with Rib at different concentrations. Sample protein concentrations were quantified with the BCA Protein Assay Kit (Pierce, Rockford, IL, USA). Equivalent amounts of protein $(20-30 \mu \mathrm{g})$ were resolved on $15 \%$ SDS-PAGE gels and transferred to nitrocellulose membranes. Membranes were then incubated, respectively, with anti-AGE 6D12 monoclonal antibody (TransGenic, Kobe, Japan), anti-pentosidine PEN12 monoclonal antibody (TransGenic), anti-RAGE H-300 rabbit polyclonal antibody (Santa Cruz), phosphor-NF- $\kappa$ B p65 (Ser536) 93H1 polyclonal antibody (CST, Danvers, MA, USA), NF- $\kappa$ B p65 E498 polyclonal antibody (CST), TNF- $\alpha$ polyclonal antibody (CST), anti-GFAP GA5 monoclonal antibody (CST) or anti- $\beta$ actin monoclonal antibody (Sigma) overnight at $4{ }^{\circ} \mathrm{C}$. Each membrane was washed three times with PBS with $0.1 \%$ (v/v) Tween-20 (PBST, pH 7.4), then incubated with horseradish peroxidase-conjugated anti-mouse $\operatorname{lgG}$ at $37^{\circ} \mathrm{C}$ for $1 \mathrm{~h}$. The membranes were again washed three times with PBST, and then immunoreactive bands were visualized using enhanced chemiluminescence detection reagents (Applygen, Beijing, China). The protein bands were visualized after exposure of the membranes to Kodak X-ray film and quantified by Quantity One 1D analysis software 4.5.2 (Bio-Rad, Hercules, CA, USA).

GFAP immunofluorescence staining and immunohistochemistry staining. Cellular GFAP immunocytofluorescence staining was performed as described. ${ }^{50}$ Two days after treatment with Rib, cells were fixed with $3 \%$ paraformaldehyde in PBS for 30 min and permeabilized with $0.1 \%$ Nonidet P-40 in PBS for 10 min. After incubation in $10 \%$ normal goat serum in PBS at $37^{\circ} \mathrm{C}$ for $60 \mathrm{~min}$, cells were labeled with an anti-GFAP antibody diluted in PBS overnight at $4{ }^{\circ} \mathrm{C}$. Cover slips were then rinsed with PBS and subsequently incubated with Alexa 488-conjugated anti-mouse IgG (Invitrogen, Carlsbad, CA, USA) for $2 \mathrm{~h}$. Pictures were taken with an Olympus FV1000 laser scanning confocal microscope (Olympus, Tokyo, Japan). Hippocampal GFAP immunohistochemistry staining was performed as described. ${ }^{51}$ Mouse brains were immersed in $4 \%$ paraformaldehyde for $48 \mathrm{~h}$ immediately after they were dissected out. After fixation, brains were 
embedded in paraffin blocks. Five-micrometer thick sections were processed for immunohistochemical analyses. Deparaffinized and hydrated sections were incubated in Target Retrieval Solution at $95^{\circ} \mathrm{C}$ for $30 \mathrm{~min}$ for enhancement of immunoreactivity and then permeabilized with $0.3 \% \mathrm{H}_{2} \mathrm{O}_{2}$ in absolute methanol for 10 min to block endogenous peroxidase and incubated in $10 \%$ normal goat serum in PBS at room temperature for $30 \mathrm{~min}$. The specimens were incubated overnight at $4{ }^{\circ} \mathrm{C}$ in anti-GFAP antibody solution diluted in PBS. After washing with PBS, sections were incubated with biotin-labeled secondary antibodies $\left(37^{\circ} \mathrm{C}, 1 \mathrm{~h}\right)$. The immunoreaction was detected using horseradish peroxidase-labeled antibodies $\left(37^{\circ} \mathrm{C}, 1 \mathrm{~h}\right)$ and red staining was visualized with an AEC system (Zhongshan Goldenbridge Biotechnology, Beijing, China). Slides were lightly stained with Harris' hematoxylin and mounted with GVA aqueous mounting medium (Zhongshan Goldenbridge Biotechnology) for observation by light microscopy (Nikon Optical, Tokyo, Japan).

Data analysis. All values reported are means \pm S.E. unless otherwise indicated. Data analysis was performed by one-way analysis of variance (ANOVA) using Origin 7.0 statistical software. Differences with a probability level of $95 \%$ $(P<0.05)$ were considered significant.

\section{Conflict of Interest}

The authors declare no conflict of interest.

Acknowledgements. We thank Dr. Peter S McPherson of McGill University for comments on this manuscript. This work was supported by grants from the 973Projects (2012CB911004, 2010CB912303), the Natural Scientific Foundation of China NSFC (31270868, 31200601, 81100610) and Queensland-Chinese Academy of Sciences Biotechnology Fund (GJHZ1131, GJHZ201302).

1. Ramasamy R, Vannucci SJ, Du Yan SS, Herold K, Yan SF, Schmidt AM. Advanced glycation end products and RAGE: a common thread in aging, diabetes, neurodegeneration, and inflammation. Glycobiology 2005; 15: 16R-28R.

2. Kalugai I. Michel-Eugene Chevreul, 1786-1889. Korot 1980; 7: 796-802.

3. Wei $Y$, Han CS, Zhou J, Liu Y, Chen L, He RQ. D-ribose in glycation and protein aggregation. Biochim Biophys Acta 2012; 1820: 488-494.

4. Su T, Xin L, He YG, Wei Y, Song YX, Li WW et al. The abnormally high level of uric d-ribose for type-2 diabetics. Prog Biochem Biophys 2013; 40: 816-825.

5. Keller PJ, Kim SU, Bown DH, Chen HC, Kohnle A, Bacher A et al. Biosynthesis of riboflavin: mechanism of formation of the ribitylamino linkage. Biochemistry 1988; 27 1117-1120.

6. Racker E. Mechanisms of synthesis of adenosine triphosphate. Adv Enzymol Relat Subj Biochem 1961; 23: 323-399.

7. Chen L, Wei $Y$, Wang $X$, He R. D-ribosylated Tau forms globular aggregates with high cytotoxicity. Cell Mol Life Sci 2009; 66: 2559-2571.

8. Chen L, Wei Y, Wang X, He R. Ribosylation rapidly induces alpha-synuclein to form highly cytotoxic molten globules of advanced glycation end products. PLoS One 2010; 5: e9052.

9. Wei Y, Chen L, Chen J, Ge L, He RQ. Rapid glycation with D-ribose induces globular amyloid-like aggregations of BSA with high cytotoxicity to SH-SY5Y cells. BMC Cell Biol 2009; 10: 10

10. Han C, Lu Y, Wei Y, Liu Y, He R. D-ribose induces cellular protein glycation and impairs mouse spatial cognition. PLoS One 2011; 6: e24623.

11. Pugliese G, Pricci F, Romeo G, Pugliese F, Mene P, Giannini $S$ et al. Upregulation of mesangial growth factor and extracellular matrix synthesis by advanced glycation end products via a receptor-mediated mechanism. Diabetes 1997; 46: 1881-1887.

12. Ramasamy R, Yan SF, Herold K, Clynes R, Schmidt AM. Receptor for Advanced Glycation End Products. Ann N Y Acad Sci 2008; 1126: 7-13.

13. Chavakis T, Bierhaus A, Nawroth PP. RAGE (receptor for advanced glycation end products): a central player in the inflammatory response. Microbes Infect 2004; 6 : 1219-1225.

14. Hofmann MA, Drury S, Fu C, Qu W, Taguchi A, Lu Y et al. RAGE mediates a novel proinflammatory axis: a central cell surface receptor for $\mathrm{S} 100 /$ calgranulin polypeptides. Cell 1999; 97: 889-901.

15. Seilhean $D$, Kobayashi $K$, He $Y$, Uchihara $T$, Rosenblum $O$, Katlama $C$ et al. Tumor necrosis factor-alpha, microglia and astrocytes in AIDS dementia complex. Acta Neuropathol 1997; 93: 508-517.

16. Radaelli E, Ceruti R, Patton V, Russo M, Degrassi A, Croci V et al. Immunohistopathological and neuroimaging characterization of murine orthotopic xenograft models of glioblastoma multiforme recapitulating the most salient features of human disease. Histo Histopathol 2009; 24: 879-891.

17. Das A, Banik NL, Ray SK. N-(4-Hydroxypheny)) retinamide induced both differentiation and apoptosis in human glioblastoma T98G and U87MG cells. Brain Res 2008; 1227: 207-215.
18. Xu JP, Liu H, Bian XW, Chen JH, Zhou XD, Wu YZ. Effect of nordy on biological behaviors of malignant glioma cell line U87MG and the analysis of differential expression proteome. Zhonghua Bing Li Xue Za Zhi 2007; 36: 609-613.

19. Tian XX, Ng HK, Pang CS, Zheng J, Du J. Mechanism of antisense epidermal growth factor receptor cDNA in growth suppression of glioblastomas cells. Zhonghua Bing Li Xue Za Zhi 2003; 32: 242-246.

20. Agnew WF, Crone C. Permeability of brain capillaries to hexoses and pentoses in the rabbit. Acta Physiol Scand 1967; 70: 168-175.

21. Smith MA, Taneda S, Richey PL, Miyata S, Yan SD, Stern D et al. Advanced Maillard reaction end products are associated with Alzheimer disease pathology. Proc Natl Acad Sci USA 1994; 91: 5710.

22. Takeda A, Yasuda T, Miyata T, Goto Y, Wakai M, Watanabe M et al. Advanced glycation end products co-localized with astrocytes and microglial cells in Alzheimer's disease brain. Acta Neuropathol 1998: 95: 555-558.

23. Segal S, Foley J. The metabolism of D-ribose in man. J Clin Invest 1958; 37: 719

24. Murphy SP, Allen LH. Nutritional importance of animal source foods. J Nutr 2003; 133: 3932S-3035S.

25. Powers HJ. Riboflavin (vitamin B-2) and health. Am J Clin Nutr 2003; 77: 1352-1360.

26. Gross M, Kormann B, Zollner N. Ribose administration during exercise: effects on substrates and products of energy metabolism in healthy subjects and a patient with myoadenylate deaminase deficiency. J Mol Med 1991; 69: 151-155.

27. Shecterle LM, Terry St KR, Cyr JA. The patented uses of D-ribose in cardiovascular diseases. Recent Pat Cardiovasc Drug Discov 2010; 5: 138-142.

28. Biessels GJ, Staekenborg S, Brunner E, Brayne C, Scheltens P. Risk of dementia in diabetes mellitus: a systematic review. Lancet Neurol 2006; 5: 64-74.

29. Ott A, Stolk RP, van Harskamp F, Pols HA, Hofman A, Breteler MM. Diabetes mellitus and the risk of dementia: the Rotterdam Study. Neurology 1999; 53: 1937-1942.

30. Hernandez-Fonseca JP, Rincon J, Pedreanez A, Viera N, Arcaya JL, Carrizo E et al. Structural and ultrastructural analysis of cerebral cortex, cerebellum, and hypothalamus from diabetic rats. Exp Diabetes Res 2009; 2009: 329632.

31. Ponath G, Schettler C, Kaestner F, Voigt B, Wentker D, Arolt V et al. Autocrine S100B effects on astrocytes are mediated via RAGE. J Neuroimmunol 2007; 184: 214-222.

32. Schmidt AM, Du Yan S, Wautier JL, Stern D. Activation of receptor for advanced glycation end products: a mechanism for chronic vascular dysfunction in diabetic vasculopathy and atherosclerosis. Circ Res 1999; 84: 489-497.

33. Basta G, Schmidt AM, De Caterina R. Advanced glycation end products and vascular inflammation: implications for accelerated atherosclerosis in diabetes. Cardiovasc Res 2004; 63: 582-592.

34. Bierhaus A, Wolf J, Andrassy M, Rohleder N, Humpert PM, Petrov D et al. A mechanism converting psychosocial stress into mononuclear cell activation. Proc Natl Acad Sci USA 2003; 100: 1920

35. Bierhaus A, Schiekofer S, Schwaninger M, Andrassy M, Humpert PM, Chen J et al. Diabetes-associated sustained activation of the transcription factor nuclear factor- $\mathrm{k} B$. Diabetes 2001; 50: 2792-2808.

36. Ghosh S, Karin M. Missing pieces in the NF-B puzzle. Cell 2002; 109: S81-S96.

37. Tak PP, Firestein GS. NF-kappaB: a key role in inflammatory diseases. J Clin Invest 2001; 107: $7-12$

38. Bonizzi G, Karin M. The two NF-kB activation pathways and their role in innate and adaptive immunity. Trends Immunol 2004; 25: 280-288.

39. Li J, Schmidt AM. Characterization and functional analysis of the promoter of RAGE, the receptor for advanced glycation end products. J Biol Chem 1997; 272: 16498.

40. Takeuchi M, Bucala R, Suzuki T, Ohkubo T, Yamazaki M, Koike T et al. Neurotoxicity of advanced glycation end-products for cultured cortical neurons. J Neuropathol Exp Neurol 2000; 59: 1094-1105.

41. Alikhani M, MacLellan CM, Raptis M, Vora S, Trackman PC, Graves DT Advanced glycation end products induce apoptosis in fibroblasts through activation of ROS, MAP kinases, and the FOXO1 transcription factor. Am J Physiol Cell Physiol 2007; 292: $\mathrm{C} 850-\mathrm{C} 856$

42. Maragakis NJ, Rothstein JD. Mechanisms of disease: astrocytes in neurodegenerative disease. Nat Clin Pract Neurol 2006; 2: 679-689.

43. Holmberg B, Rosengren L, Karlsson JE, Johnels B. Increased cerebrospinal fluid levels of neurofilament protein in progressive supranuclear palsy and multiple-system atrophy compared with Parkinson's disease. Mov Disord 1998; 13: 70-77.

44. Akiyama H, Barger S, Barnum S, Bradt B, Bauer J, Cole GM et al. Inflammation and Alzheimer's disease. Neurobiol Aging 2000; 21: 383-421.

45. Bruunsgaard H, Andersen-Ranberg K, Jeune B, Pedersen AN, Skinhøj P, Pedersen BK. A high plasma concentration of TNF- $\alpha$ is associated with dementia in centenarians. J Gerontol A Biol Sci Med Sci 1999; 54: M357-M364.

46. Nie CL, Wei Y, Chen X, Liu YY, Dui W, Liu Y et al. Formaldehyde at low concentration induces protein tau into globular amyloid-like aggregates in vitro and in vivo. PLOS ONE 2007; 2: e629.

47. Morris R. Developments of a water-maze procedure for studying spatial learning in the rat. J Neurosci Methods 1984; 11: 47-60.

48. Weng D, Lu Y, Wei $Y$, Liu $Y$, Shen P. The role of ROS in microcystin-LR-induced hepatocyte apoptosis and liver injury in mice. Toxicology 2007; 232: 15-23.

49. Johnson RN, Metcalf PA, Baker JR. Fructosamine: a new approach to the estimation of serum glycosylprotein. An index of diabetic control. Clin Chim Acta 1983; 127: 87-95. 
50. Koyama Y, Goldman JE. Formation of GFAP cytoplasmic inclusions in astrocytes and their disaggregation by $\alpha B-c r y s t a l l i n$. Am J Pathol 1999; 154: 1563-1572.

51. Sasaki N, Toki S, Chowei $H$, Saito $T$, Nakano $N$, Hayashi $Y$ et al. Immunohistochemical distribution of the receptor for advanced glycation end products in neurons and astrocytes in Alzheimer's disease. Brain Res 2001; 888: 256-262.
Cell Death and Disease is an open-access journal published by Nature Publishing Group. This work is licensed under a Creative Commons Attribution-NonCommercialNoDerivs 3.0 Unported License. To view a copy of this license, visit http://creativecommons.org/licenses/by-nc-nd/3.0/

Supplementary Information accompanies this paper on Cell Death and Disease website (http://www.nature.com/cddis) 